\title{
Statistical analysis of microarray gene expression data from a mouse model of toxoplasmosis
}

\author{
Shrikant Pawar ${ }^{1,2^{*}}$, Cheryl D Davis ${ }^{1,2}$, Claire A Rinehart ${ }^{1,2}$ \\ From 10 ${ }^{\text {th }}$ Annual UT-ORNL-KBRIN Bioinformatics Summit 2011 \\ Memphis, TN, USA. 1-3 April 2011
}

\section{Background}

Toxoplasmosis, caused by the protozoan parasite Toxoplasma gondii is a major cause of morbidity and mortality in patients with AIDS and an important cause of miscarriage, stillbirth and congenital disease in newborns. Previous studies have provided evidence that dietary supplementation with vitamin $\mathrm{E}$ and selenium is harmful during experimental toxoplasmosis in mice, whereas a diet deficient in vitamin $\mathrm{E}$ and selenium results in decreased numbers of tissue cysts in the brain and dramatically reduced brain pathology. The overall goal of the present study was to determine the impact of dietary supplementation with antioxidants on gene expression in the brains of non-infected mice and in mice infected with $T$. gondii using microarray analysis. RNA was isolated from the brains of C57BL/6 mice, and an Agilent Oligo Whole Mouse Genome Microarray (Agilent Technologies, Inc.) was performed. A total of 48 chips were normalized by $\mathrm{Z}$ ratios and the Data Driven Harr Fisch Normalization methods. Differentially expressed genes were identified by applying thresholds to identify significant values and the results were compared between the normalization methods. These differentially expressed genes and their respective fold change ratios were used in Ingenuity Pathway Analysis (IPA) software to analyze the pathways involved with these genes.

\section{Acknowledgements}

Support from the National Center for Research Resources NIH Grant Number 2 P20 RR-16481 and from the WKU Bioinformatics and Information Science Center is gratefully acknowledged.

\footnotetext{
* Correspondence: pawar1550@gmail.com

'Department of Biology, Western Kentucky University, Bowling Green, KY 42101, USA

Full list of author information is available at the end of the article
}

\section{Author details}

'Department of Biology, Western Kentucky University, Bowling Green, KY 42101, USA. ${ }^{2}$ Bioinformatics and Information Science Center, Western Kentucky University, Bowling Green, KY 42101, USA.

Published: 5 August 2011

doi:10.1186/1471-2105-12-S7-A19

Cite this article as: Pawar et al: Statistical analysis of microarray gene expression data from a mouse model of toxoplasmosis. BMC

Bioinformatics 2011 12(Suppl 7):A19.
Submit your next manuscript to BioMed Central and take full advantage of:

- Convenient online submission

- Thorough peer review

- No space constraints or color figure charges

- Immediate publication on acceptance

- Inclusion in PubMed, CAS, Scopus and Google Scholar

- Research which is freely available for redistribution

\section{() Biomed Central}

\section{Biomed Central}

